\title{
PETA SOSIAL EKONOMI UMMAT (STUDI TERHADAP LEMBAGA EKONOMI DALAM PEMBERDAYAAN MASYARAKAT)
}

\author{
Muhlasin $^{1}$, Muhammad Soim ${ }^{2}$ \\ ${ }^{1,2}$ Fakultas Dakwah dan Komunikasi UIN Sultan Syarif Kasimska Riau \\ Jl. HR Soebrantas Km 15 Simpangbaru, Tampan, Pekanbaru 28293 \\ Email: Muhlasin.Syahlan@gamil.com
}

\begin{abstract}
Abstrak
Zakat sebagai sarana distribusi pendapatan dan pemerataan ekonomi, serta sarana berbuat kebajikan bagi kepentingan masyarakat menduduki peran penting dalam perekonomian masyakat secara umum maupun kalangan Muslim, karenanya menarik untuk dikaji kembali sebagai salah satu potensi dana umat yan sangat besar guna memecahkan berbagai masalah sosial masyarakat. Ekonomi Islam adalah kumpulan prinsip-prinsip umum tentang ekonomi yang kita ambil dari Al-Qur'an, Sunnah, dan pondasi ekonomi yang kita bangun atas dasar-dasar pokok itu dengan mempertimbangkan kondisi lingkungan dan waktu, sejalan dengan pendapat Dr. Muhammad Syauki Al-Fanjari "ekonomi Islam adalah segala sesuatu yang mengendalikan dan mengatur aktivitas ekonomi sesuai dengan pokok Islam dan politik ekonominya".
\end{abstract}

Kata kunci: Ekonomi Islam, Pemberdayaan, Zakat dan Wakaf

\section{Pemberdayaan Ekonomi}

Program pengentasan kemiskinan yang dijalankan oleh pemerintah masih belum memberikan dampak yang signifikan terhadap menurunkan tingkat kemiskinan. Mereka membutuhkan dukungan dari sub sistem lain termasuk zakat. Zakat merupakan salah satu instrument fiskal Islam yang telah memberikan peranan cukup signifikan dalam sistem ekonomi Islam. Potensi zakat akan mampu mencakup berbagai macam aspek termasuk untuk program pengentasan kemiskinan dalam bentuk sistem jaminan sosial. Zakat dapat dipergunakan dalam berbagai bentuk sistem jaminan sosial, seperti asuransi tenaga kerja, asuransi pensiun dan asuransi jiwa. Serta untuk mengatasi berbagai macam masalah seperti perumahan, akses permodalan dan pendidikan bagi si miskin dapat dilakukan melalui memaksimalkan pengelolaan dan pendayagunaan zakat.

Ekonomi secara istilah berasal dari Yunani, yaitu oicos (rumah tangga) dan nomos (aturan/norma), yang jika kedua kata ini digabungkan, maka bermakna cara untuk mengatur urusan rumah tangga. Walaupun dalam perkembangannya ekonomi menjadi ilmu yang mengatur urusan-urusan kenegaraan yang mengurusi hajat hidup orang banyak. Secara popular, ilmu ekonomi didefinisikan sebagai ilmu yang mempelajari upaya manusia baik secara individu maupun bermasyarakat dalam menentukan pilihan-pilihan terhadap sumber daya yang terbatas jumlahnya untuk memenuhi kebutuhan yang tidak terbatas jumlahnya. Akan tetapi jika yang dimaksud teori atau prinsip ataupun tata cara berekonomi, maka al-Qur'an sangat banyak menjelaskan hal itu.

Adapun kata ekonomi diartikan ke bahasa arab yaitu al-iqtishad (الأقتصاد) yang berasal dari kata (قصد)yang berarti maksud, yang al-iqtishad itu dimaknai melakukan sesuatu dengan ketentuan dan aturan-aturannya, tidak kurang dan tidak lebih. maka intisari atau tashrifnya (bentuk perubahannya) dari kata ini terdapat dalam al-Qur'an pada 5 surat diantaranya : Surat An-Nahl 16:9, Al-Luqman 
31:19,32, Al-Maidah 5:66, At-Taubah 9:42,AlFathir $35: 32{ }^{1}$

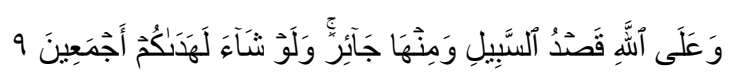

Allah (menerangkan) jalan yang lurus, dan di antara jalan-jalan ada yang bengkok. dan Jikalau Dia menghendaki, tentulah Dia memimpin kamu semuanya (kepada jalan yang benar).

Ayat ini kembali mengingatkan akan nikmat-nikmat yang Allah berikan kepada hamba-hamba-Nya, termasuk nikmat hidayah dan petunjuk kepada jalan yang benar. Allah dalam ayat ini berfirman bahwa di hadapan manusia terbentang dua jalan. Pertama adalah jalan yang dihamparkan Allah kepada manusia yaitu jalan kesederhanaan dan jalan tengah yang membawa manusia kepada tujuan yang benar lewat sirath mustaqim. Jalan yang kedua adalah jalan menyimpang yang membawa manusia ke arah kesesatan. Siapa saja yang berlalu di jalan ini akan terjebak dalam malapetaka dan tak akan sampai ke tujuan yang benar. Setiap orang harus memilih dari kedua itu jalan manakah yang akan dia lalui. Allah Swt tidak pernah memaksa hambaNya untuk memilih jalan petunjuk dan hidayah ilahi. Sebab paksaan tidak akan ada gunanya. Allah Swt telah memberikan kebebasan kepada setiap orang untuk memilih.

Dari ayat tadi terdapat dua pelajaran yang dapat dipetik:

1. Di antara hal yang oleh Allah dipandang sebagai keharusan bagi-Nya adalah memberi petunjuk dan hidayah kepada hamba-hamba-Nya. Namun manusialah yang harus memilih maukah ia menerima hidayah atau tidak

2. Kebebasan dalam memilih telah diberikan kepada manusia dan inilah yang diinginkan oleh Allah Swt. Karena itu, tidak berhak

\footnotetext{
${ }^{1}$ Muhammad Fuad Abdul al Baqi, Al-Mu'jam al Mufarahros li alfadhil al Qur'anil Karim, (Indonesia: Maktabah duhlan). H. 693
}

untuk memaksa siapapun agar mengikuti Islam dan jalan petunjuk. $^{2}$

Ekonomi Islam merupakan ilmu yang mempelajari perilaku ekonomi manusia yang perilakunya diatur berdasarkan aturan agama Islam dan didasari dengan tauhid sebagaimana dirangkum dalam rukun iman dan rukun Islam.

Kata Islam setelah "Ekonomi" dalam ungkapan Ekonomi Islam berfungsi sebagai identitas tanpa mempengaruhi makna atau definisi ekonomi itu sendiri. Karena definisinya lebih ditentukan oleh perspektif atau lebih tepat lagi worldview yang digunakan sebagai landasan nilai. Sedang ekonomi adalah masalah menjamin berputarnya harta diantara manusia, sehingga manusia dapat memaksimalkan fungsi hidupnya sebagai hamba Allah untuk mencapai falah di dunia dan akherat (hereafter). Ekonomi adalah aktifitas yang kolektif. Berikut ini definisi Ekonomi dalam Islam menurut Para Ahli :

a. S.M. Hasanuzzaman, "ilmu ekonomi Islam adalah pengetahuan dan aplikasi ajaranajaran dan aturan-aturan syariah yang mencegah ketidakadilan dalam pencarian dan pengeluaran sumber-sumber daya, guna memberikan kepuasan bagi manusia dan memungkinkan mereka melaksanakan kewajiban-kewajiban mereka terhadap Allah dan masyarakat."

b. M.A. Mannan, "ilmu ekonomi Islam adalah suatu ilmu pengetahuan social yang mempelajari permasalahan ekonomi dari orang-orang memiliki nilai-nilai Islam."

c. Khursid Ahmad, ilmu ekonomi Islam adalah "suatu upaya sistematis untuk mencoba memahami permasalahan ekonomi dan perilaku manusia dalam hubungannya dengan permasalahan tersebut dari sudut pandang Islam."

d. M.N. Siddiqi, ilmu ekonomi Islam adalah respon "para pemikir muslim terhadap tantangan-tantangan ekonomi zaman

${ }^{2}$ Hamka, Tafsir Al-Azhar, Penerbit Pustaka Panjimas, Jakarta, h. 
mereka. Dalam upaya ini mereka dibantu oleh Al Qur'an dan As Sunnah maupun akal dan pengalaman."

e. M. Akram Khan, "ilmu ekonomi Islam bertujuan mempelajari kesejahteraan manusia (falah) yang dicapai dengan mengorganisir sumber-sumber daya bumi atas dasar kerjasama dan partisipasi."

f. Louis Cantori, "ilmu ekonomi Islam tidak lain merupakan upaya untuk merumuskan ilmu ekonomi yang berorientasi manusia dan berorientasi masyarakat yang menolak ekses individualisme dalam ilmu ekonomi klasik."

g. individualisme dalam ilmu ekonomi klasik."

1. Ciri Ekonomi Islam

Tidak banyak yang dikemukakan dalam Al Qur'an, dan hanya prinsip-prinsip yang mendasar saja. Karena alasan-alasan yang sangat tepat, Al Qur'an dan Sunnah banyak sekali membahas tentang bagaimana seharusnya kaum Muslim berprilaku sebagai produsen, konsumen dan pemilik modal, tetapi hanya sedikit tentang sistem ekonomi. Ekonomi dalam Islam harus mampu memberikan kesempatan seluas-luasnya kepada setiap pelaku usaha. Selain itu, ekonomi islam menekankan empat sifat, antara lain:

a. Kesatuan (unity)

b. Keseimbangan (equilibrium)

c. Kebebasan (free will)

d. Tanggungjawab (responsibility)

Manusia sebagai wakil (khalifah)

Tuhan di dunia tidak mungkin bersifat individualistik, karena semua (kekayaan) yang ada di bumi adalah milik Allah semata, dan manusia adalah kepercayaannya di bumi. Didalam menjalankan kegiatan ekonominya, Islam sangat mengharamkan kegiatan riba, yang dari segi bahasa berarti "kelebihan".

Secara garis besar ekonomi Islam memiliki beberapa prinsip dasar: a. Berbagai sumber daya dipandang sebagai pemberian atau titipan dari Allah swt kepada manusia.

b. Islam mengakui pemilikan pribadi dalam batas-batas tertentu.

c. Kekuatan penggerak utama ekonomi Islam adalah kerja sama.

d. Ekonomi Islam menolak terjadinya akumulasi kekayaan yang dikuasai oleh segelintir orang saja.

e. Ekonomi Islam menjamin pemilikan masyarakat dan penggunaannya direncanakan untuk kepentingan banyak orang.

f. Seorang muslim harus takut kepada Allah swt dan hari penentuan di akhirat nanti.

g. Zakat harus dibayarkan atas kekayaan yang telah memenuhi batas (nisab)

h. Islam melarang riba dalam segala bentuk.

2. Konsep Dasar

Melihat keadaan keuangan modern saat ini yang banyak dipengaruhi oleh konsep kapitalis yang membolehkan banyak apa yang telah dilarang dalam agama Islam, ummat Islam akhirnya berusaha mencari suatu alternatif sistem keuangan yang dapat menghindarkan diri mereka dari berbagai macam kegiatan dan transaksi yang bertentangan dengan hukum yang mereka fahami dalam agama mereka.

Dengan konsep dasar merujuk kepada Ayat-ayat dan Hadits-hadits yang menolak banyak kegiatan transaksi dan kontrak ini, beberapa usaha kaum Muslim telah berhasil membuat suatu konsep dasar keuangan Islam untuk mewujudkan suatu konsep keuangan alternatif yang berlandaskan Syari'ah yang mereka dambakan selama ini. Bermula dengan usaha Ahmed El-Naggar pada tahun 1963 di Mesir dengan mendirikan sebuah bank lokal yang menghindarkan segala transaksinya dari riba (berlandaskan 
syar'iah) dan diikuti oleh banyak usaha akademisi dan praktisi dari kaum Muslim lainnya. Dan kini, perkembangan keuangan Islam semakin pesat di berbagai belahan dunia Timur dan Barat, dan semakin diminati oleh banyak orang untuk dipelajari secara lebih mendalam.

3. Perbedaan Ekonomi Islam Dengan Ekonomi Konvensional:

Krisis ekonomi yang sering terjadi dipengaruhi oleh sistem ekonomi konvensional, yang mengedepankan sistem bunga sebagai instrumen provitnya. Berbeda dengan apa yang ditawarkan sistem ekonomi syariah, dengan instrumen provitnya, yaitu sistem bagi hasil. Sistem ekonomi syariah sangat berbeda dengan ekonomi kapitalis, sosialis maupun komunis. Ekonomi syariah bukan pula berada ditengah-tengah ketiga sistem ekonomi itu. Sangat bertolak belakang dengan kapitalis yang lebih bersifat individual, sosialis yang memberikan hampir semua tanggungjawab kepada warganya serta komunis yang ekstrim, ekonomi Islam menetapkan bentuk perdagangan serta perkhidmatan yang boleh dan tidak boleh di transaksikan. Ekonomi dalam Islam harus mampu memberikan kesejahteraan bagi seluruh masyarakat, memberikan rasa adil, kebersamaan dan kekeluargaan serta mampu memberikan kesempatan seluas-luasnya kepada setiap pelaku usaha. ${ }^{3}$

Sesungguhnya

politik pengembangan ekonomi dalam Islam itu perhatian dibidang ekonomi yang merupakan bagian dari politik syari'ah dan apa yang menjadi tuntutannya tentang pemeliharaan sumber-sumber ekonomi dan pengembangannya, meningkatkan kemampuan produksi dengan mengembangkan seni dan metodenya, dan

\footnotetext{
${ }^{3}$ http://fahmyzone.blogspot.com/2013/04/pengertian-
} ekonomi-islam.html\#sthash.uHXlpydI.dpuf hal-hal lain yang menjadi keharusan dalam merealisasikan kesejahteraan ekonomi ummat, memenuhi kebutuhan yang mendasar dan memerangi kemiskinan. ${ }^{4}$

Nilai-nilai dasar ekonomi syari'at adalah yang berfalsafah tauhid, yang tidak bertentangan dengan syari'at, seperti tidak adanya unsur memperdaya, menipu, keuntungan sepihak, menutup-nutupi, dan segala yang dapat merugikan orang lain. Menurut Saefudin meliputi: kepemilikan, keseimbangan, dan keadilan. ${ }^{5}$

\section{Pemberdayaan Zakat}

Konsep pemerataan yang dianjurkan dalam Islam telah berhasil dibuktikan pada masa kekhalifahan Umar bin Abdul Aziz, dimana pada masa itu beliau pun mengalami kesulitan dalam pengelolaan zakat, namun kesulitan yang dihadapi beliau bukanlah kesulitan untuk mencari muzakki (orang yang mampu membayar zakat) melainkan kesulitan yang dihadapi adalah untuk mencari mustahik (orang yang membutuhkan), karena semua penduduk pada masa kekhalifahan Umar bin Abdul Aziz tidak ada yang mengalami kekurangan. Bahkan semua penduduknya tergolong pada penduduk yang wajib zakat. Ini membuktikan bahwa konsep yang dibawa oleh ajaran Islam telah mampu dibuktikan, meskipun pada situasi dan kondisi yang berbeda. Beberapa bentuk pemberian zakat berdasarkan tipologi orang miskin dalam tiga golongan, yaitu (Qadir, 2001: 45): 1.

Golongan yang tidak mempunyai kemampuan sama sekali untuk berusaha memenuhi kebutuhan hidupnya secara mandiri. Faktor yang menyebabkan mereka tidak mampu adalah seperti faktor usia

4 Muhammad, Lembaga-lembaga Keuangan Ummat Kontemporer (Cet.I; Yogyakarta: UII Press, 2000), h. 2

5 Karnaen A. Perwataatmadja, Membumikan Ekonomi Islam di Indonesia (Depok: Usaha Kami, 1996), h. 251 
yang telah lanjut (lansia) atau karena cacat jasmani permanen, yang menyebabkan mereka tidak mampu memenuhi kebutuhannya secara mandiri, maka cara pengentasannya adalah dengan memberikan jaminan hidup secara rutin dari dana zakat, bantuan zakat yang diberikan kepada golongan ini adalah zakat dalam bentuk bantuan konsumtif.

Mereka yang tergolong masih sehat fisik jasmani, tetapi tidak memiliki keterampilan apa pun, dimana inilah yang sebahagian terdapat di masyarakat yaitu masyarakat miskin yang kurang berpendidikan dan kurang keahlian. Pengentasan kemiskinan untuk golongan ini adalah diberikan pelatihan dan pendidikan khusus, dan selanjutnya dipekerjakan pada unit-unit usaha ekonomi yang dikelola oleh amil zakat setempat sehingga mereka bisa mandiri dalam memenuhi kebutuhan hidupnya.

Mereka miskin karena suatu hal yang disebabkan terjadi musibah -seperti bencana alam yang telah menghancurkan semua harta benda yang dimiliki-, sedangkan fisik dan mentalnya masih potensial untuk bekerja dan berusaha, tetapi tidak memiliki modal, maka langkah pengentasannya adalah memberikan pinjaman modal usaha dari dana zakat.. Berdasarkan tipologi orang miskin yang dikategorikan oleh Abdurrachman Qadir tersebut, maka dapat disusun suatu sistem jaminan sosial dengan berbasis pada pendayagunaan zakat. Zakat dapat dipergunakan dalam berbagai bentuk sistem jaminan sosial, seperti asuransi tenaga kerja, asuransi pensiun dan asuransi jiwa. Serta untuk mengatasi berbagai macam masalah seperti perumahan, akses permodalan dan pendidikan bagi si miskin dapat dilakukan melalui memaksimalkan pengelolaan dan pendayagunaan zakat. Dengan pendayagunaan zakat sebagai suatu sistem jaminan sosial diharapkan program pengentasan kemiskinan dapat saling terintegratif dengan program pemerintah. Namun agar zakat ini dapat optimal sebagai salah satu instrument dalam penerapan sistem jaminan sosial ialah diarahkan pada zakat yang bersifat produktif. Dana zakat yang terhimpun dikelola sepenuhnya untuk sesuatu yang produktif, sehingga dana zakat yang terhimpun dapat tumbuh dan berkembang. Selanjutnya dari hasil dana zakat tersebut dialokasikan sepenuhnya sebagai salah satu pendanaan.

\section{Pemberdayaan wakaf}

Wakaf merupakan salah satu sumber dana sosial potensial yang erat kaitannya dengan kesejahteraan umat disamping zakat, infaq dan shadaqah. Di Indonesia, wakaf telah dikenal dan dilaksanakan oleh umat Islam sejak agama Islam masuk di Indonesia. Sebagai salah satu institusi keagamaan yang erat hubungannya dengan sosial ekonomi, wakaf telah banyak membantu pembangunan secara menyeluruh di Indonesia, baik dalam pembangunan sumber daya manusia maupun dalam pembangunan sumber daya sosial. Tak dapat dipungkiri, bahwa sebagian besar rumah ibadah, peguruan Islam dan lembaga-lembaga keagamaan Islam lainnya dibangun di atas tanah wakaf.

Salah satu aspek ajaran Islam yang berdimensi spiritual, wakaf juga merupakan ajaran yang menekankan pentingnya kesejahteraan ekonomi (dimensi sosial). Karena itu pendefinisian ulang terhadap wakaf agar memiliki makna yang lebih relevan dengan kondisi riil persoalan kesejahteraan menjadi sangat penting. Dimensi tanggungjawab sosial dalam wakaf berarti menempatkan wakaf tidak sematamata sebagai ibadah yang akan mendapatkan ganjaran dari Allah SWT tetapi juga sebagai nilai positif dalam hubungan sosial yang lebih luas. Pertemuan dimensi 'atas' (ridha Allah SWT) dengan dimensi 'bawah' (kemanusiaanprofan) melekat pada wakaf sebagai dwi- 
tunggal yang menggerakkan kehidupan masyarakat.

Sepanjang sejarah Islam, wakaf merupakan sarana dan modal yang amat penting dalam memajukan perkembangan agama. Dalam sejarah peradaban Islam, sejak awal ditasyrik-kannya, wakaf telah memiliki peran yang sangat penting dalam langkah-langkah meningkatkan kesejahteraan sosial umat Islam pada masa itu dan masa-masa selanjutnya. Hal ini disebabkan bahwa prinsip wakaf adalah memadukan dimensi ketakwaan dan kesejahteraan

Terbukti bahwa manfaat wakaf, pada masa keemasan Islam, telah melahirkan ilmuwan-ilmuwan tersohor dan kemajuan ilmu pengetahuan yang sangat pesat. Dengan pesatnya perkembangan zaman, wakaf tidak lagi hanya diasosiasikan pada obyek wakaf berupa tanah, akan tetapi sudah merambah kepada wakaf bentuk lain seperti benda bergerak berupa uang. Di Indonesia, beberapa jenis wakaf baru tentang wakaf telah diakonomodasi oleh UU No 41 tahun 2004 tentang Wakaf, sebagai bentuk penyempurnaaan konsep wakaf yang terdapat dalam kompilasi hukum Islam. Wakaf telah banyak membantu pengembangan dalam berbagai ilmu, baik ilmu agama maupun ilmu pengetahuan lainnya.Biasanya, hasil pengelolaan harta benda wakaf digunakan untuk membangun fasilitas-fasilitas publik di bidang keagamaan, kesehatan, pendidikan, pembangunan masjid, rumah sakit, perpustakaan, gedung-gedung, dan lainnya.

Merujuk pada data Departemen Agama (Depag) RI, jumlah tanah wakaf di Indonesia mencapai 2.686.536.656,68 meter persegi atau sekitar 268.653,67 hektar (ha) yang tersebar di 366.595 lokasi di seluruh Indonesia. Jumlah tanah wakaf yang besar ini merupakan harta wakaf terbesar di dunia.Sayangnya, tanah wakaf tersebut sebagian besar baru dimanfaatkan untuk kesejahteraan masjid, kuburan, panti asuhan, dan sarana
pendidikan.Dan hanya sebagian kecil yang dikelola ke arah lebih produktif.Harta wakaf lebih banyak bersifat diam (77\%) daripada yang menghasilkan atau produktif (23\%). fakta perwakafan di Indonesia, punya aset besar tapi belum dioptimalkan.

\section{Pemberdayaan Sosial}

Pemberdayaan sosial merupakan upaya yang diarahkan untuk mewujudkan warga negara yang mengalami masalah sosial agar mempunyai daya, sehingga mampu memenuhi kebutuhan dasarnya (UU Nomor 112009 tentang Kesejahteraan Sosial). Pengertian ini mesti dimaknai secara arif, yaitu bahwa tujuan pemenuhan kebutuhan dasar adalah tujuan awal agar secara bertahap kehidupan yang lebih berkualitas dan kemandirian dapat dicapai. Pemberdayaan sosial secara simultan juga diarahkan agar seluruh potensi kesejahteraan sosial dapat dibangun menjadi sumber kesejahteraan sosial yang mampu berperan optimal dalam penyelenggaraan kesejahteraan sosial.

Dalam melaksanakan tugas dan fungsi pemberdayaan sosial, telah ditetapkan struktur organisasi yang menjadi wadah penggerak berjalannya fungsi secara optimal, mempertimbangkan lingkup tugas yang meliputi pemberdayaan sosial keluarga, fakir miskin, dan komunitas adat terpencil (KAT) serta pendayagunaan nilai-nilai dasar kesejahteraan sosial dan kelembagaan sosial masyarakat. Undang Undang Nomor 11 Tahun 2009 tentang Kesejahteraan Sosial Bagian Keempat Pasal 12 dan Pasal 13 telah menempatkan pemberdayaan sosial sebagai bagian integral dalam sistem kesejahteraan sosial nasional. Oleh karena itu, sangatlah proporsional jika lingkup ini dikelola secara khusus melalui satuan organisasi Direktorat Jenderal Pemberdayaan Sosial.

Dalam Al-Qur'an ditemui ayat-ayat yang berkaitan dengan pemberdayaan sosialini 
ada 2 buah surat antara lain :Q.S. AlIsra':88,Q.S. Al-Hajj:73. ${ }^{6}$

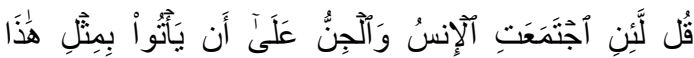

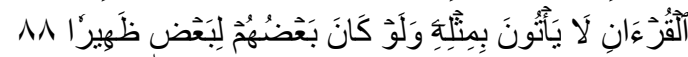

Arinya: Katakanlah: "Sesungguhnya jika manusia dan jin berkumpul untuk membuat yang serupa Al Quran ini, niscaya mereka tidak akan dapat membuat yang serupa dengan Dia, Sekalipun sebagian mereka menjadi pembantu bagi sebagian yang lain".

Diriwayatkan oleh Ibnu Ishaq dan Ibnu Jarir, dari Sa'id atau 'Ikrimah yang bersumber dari Ibnu 'Abbas bahwa Salam bin Musykam bersama-sama kawannya, kaum Yahudi, datang menghadap Nabi saw. dan berkata: "Bagaimana kami bisa mengikuti engkau, sedang engkau sendiri telah meninggalkan kiblat kami, dan yang engkau bawa tidak teratur rapi seperti Taurat. Turunkanlah kepada kami sebuah kitab yang kami kenal. Kalau tidak, kami akan mendatangkan kepadamu seperti yang engkau bawa." Maka Allah menurunkan ayat ini (alIsraa': 88) berkenaan dengan peristiwa tersebut.

$$
\text { Dalam pengalaman historis, }
$$

pemberdayaan sosial dengan perkembangan realitas sosial budaya senantiasa menjumpai dua kemungkinan. Pertama, pemberdayaan sosial mampu memberi arah, dasar filosofi, motivasi dan pedoman bagi masyarakat hingga terbentuk realitas sosial baru. Kedua, pemberdayaan sosial dipengaruhi oleh perubahan dan perkembangan sosial masyarakat, dalam arti eksistensi, bentuk dan arahnya. Hal ini memberi kecenderungan bahwa, kontekstualitas dan aktualitas penyebaran nilai-nilai subtansial Islam melalui aktifitas dakwah harus dan atau sangat

\footnotetext{
${ }^{6}$ Muhammad Fuad Abdul al Baqi, Al-Mu'jam al Mufarahros li alfadhil al Qur'anil Karim, (Indonesia: Maktabah duhlan). H. 223
}

ditentukan oleh realitas dan sistem sosial masyarakat tertentu. $^{7}$

\begin{tabular}{lrcr}
\multicolumn{1}{c}{ Oleh } & karena & itu & persfektif \\
pemberdayaan & sosial & $\begin{array}{c}\text { harus } \\
\text { mampu }\end{array}$ \\
menterjemahkan & & \multicolumn{2}{c}{ kecenderungan- }
\end{tabular}
kecenderungan yang ada dalam masyarakat. Pemberdayaan akan memiliki makna dan pengaruh, jika kita mampu memetakan medan sasaran, menterjemahkan materi secara tepat, dan cerdas menentukan strategi pendekatan, maka pemberdayaan sosial dilakukan dengan memahami sosial masyarakat tanpa meninggalkan subtansi nilai-nilai sejarah dan ajaran yang prinsipil. ${ }^{8}$

Muhammad diutus Allah SWT ke bumi tidak lain adalah untuk menyampaikan pesan kepada umat manusia tentang prinsip-prinsip kehidupan. Ketika pertama kali diutus sebagai Nabi, Muhammad dihadapkan pada setting sosial, yakni realitas masyarakat yang mempunyai keyakinan menyembah berhala jauh dari ideal-moral-teologikal ajaran yang dibawanya.

Hal ini ditujukan untuk membangun sistem dan merubah tatanan sosial yang sesuai dengan dasar filosofi Islam. Seperti apa yang dilakukan para walisongo di Indonesia misalnya, khususnya di Jawa yang telah memiliki kebudayaan yang sudah mengakar, yakni filsafat Hindu Jawa, maka dakwah Islam dilenturkan dengan tradisi-tradisi yang telah ada berabad-abad lamanya. Tradisi penduduk asli yang telah lama bersentuhan dengan tradisi Hindu Budha yang berbau paham mistisisme

\section{Pemberdayaan Budaya}

Budaya atau kebudayaan adalah bersifat spesifik manusiawi. ${ }^{9}$ Artinya,

\footnotetext{
${ }^{7}$ M. Dawam Rahardjo, Aspek Pembaharuan Pemahaman Islam, dalam Dakwah Islam dan Perubahan Sosial, Yogyakarta: Prima Duta, 1983, hlm. 135.

${ }^{8}$ Asep Muhyiddin dan Agus Ahmad Safei, Metode Pengembangan Dakwah, Bandung: Pustaka Setia, 2002, hlm. 169. Lihat Q.S Al-Anfal, 8: 7, Q.S Al-Isra, 17: 105 .

${ }^{9}$ Taufik Abdullah, "Pengantar: Islam, Sejarah dan Masyarakat",dalam Taufik Abdullah Sejarah dan
} 
manifestasi dan perwujudan dari segala aktivitas manusia sebagai upaya untuk memudahkan dan memenuhi kebutuhan hidupnya. Kebudayaan terdiri dari nilai dan simbol. Nilai-nilai budaya itu tidak kasat mata, sedangkan simbol budaya yang merupakan perwujudan nilai itulah yang kasat mata. Masjid, pasar, sekolah, rumah misalnya adalah perwujudan dari nilai-nilai budaya masyarakatnya. Setiap perwujudan aktivitas manusia nilai-nilai budaya senantiasa hadir dan semua punya nilai budaya, walau terkadang tidak merupakan simbol budaya.

Budaya atau kebudayaan berasal dari bahasa Sansekerta yaitu Buddhayah, yang merupakan bentuk jamak dari buddhi (budi atau akal) diartikan sebagai hal-hal yang berkaitan dengan budi dan akal manusia. Dalam bahasa Inggris, kebudayaan disebut culture, yang berasal dari kata Latin Colere, yaitu mengolah atau mengerjakan. Bisa diartikan juga sebagai mengolah tanah atau bertani. Kata culture juga kadang diterjemahkan sebagai "kultur" dalam bahasa Indonesia.

Kebudayaan sangat erat hubungannya dengan masyarakat. Melville J. Herskovits dan Bronislaw Malinowski mengemukakan bahwa segala sesuatu yang terdapat dalam masyarakat ditentukan oleh kebudayaan yang dimiliki oleh masyarakat itu sendiri. Istilah untuk pendapat itu adalah Cultural-Determinism. Herskovits memandang kebudayaan sebagai sesuatu yang turun temurun dari satu generasi ke generasi yang lain, yang kemudian disebut sebagai superorganic. Menurut Andreas Eppink, kebudayaan mengandung keseluruhan pengertian, nilai, norma, ilmu pengetahuan serta keseluruhan struktur-struktur sosial, religius, dan lain-lain, tambahan lagi segala pernyataan intelektual dan artistik yang menjadi ciri khas suatu masyarakat.

Menurut Edward B. Tylor, kebudayaan merupakan keseluruhan yang kompleks, yang

Masyarakat:Lintasan Historis Islam di Indoensia, (Jakarta: PustakaFirdaus, 1987). Hlm: 221 di dalamnya terkandung pengetahuan, kepercayaan, kesenian, moral, hukum, adat istiadat, dan kemampuan-kemampuan lain yang didapat seseorang sebagai anggota masyarakat. Sedangkan menurut Selo Soemardjan dan Soelaiman Soemardi, kebudayaan adalah sarana hasil karya, rasa, dan cipta masyarakat.

Dari berbagai definisi tersebut, dapat diperoleh pengertian mengenai kebudayaan yaitu sistem pengetahuan yang meliputi sistem ide atau gagasan yang terdapat dalam pikiran manusia, sehingga dalam kehidupan sehari-hari, kebudayaan itu bersifat abstrak. Sedangkan perwujudan kebudayaan adalah benda-benda yang diciptakan oleh manusia sebagai makhluk yang berbudaya, berupa perilaku dan bendabenda yang bersifat nyata, misalnya pola-pola perilaku, bahasa, peralatan hidup, organisasi sosial, religi, seni, dan lain-lain, yang kesemuanya ditujukan untuk membantu manusia dalam melangsungkan kehidupan bermasyarakat, sehingga bisa disimpulkan bahwa hasil karya cipta manusia memunculkan budaya, dan kebudayaan akan menciptakan peradaban. Budaya akan muncul dari tiga sisi, yaitu:

1. Gagasan (Wujud ideal)

Wujud ideal kebudayaan adalah kebudayaan yang berbentuk kumpulan ideide, gagasan, nilai-nilai, norma-norma, peraturan, dan sebagainya yang sifatnya abstrak; tidak dapat diraba atau disentuh. Wujud kebudayaan ini terletak dalam kepala-kepala atau di alam pemikiran warga masyarakat. Jika masyarakat tersebut menyatakan gagasan mereka itu dalam bentuk tulisan, maka lokasi dari kebudayaan ideal itu berada dalam karangan dan bukubuku hasil karya para penulis warga masyarakat tersebut.

2. Aktivitas (tindakan)

Aktivitas adalah wujud kebudayaan sebagai suatu tindakan berpola dari manusia dalam masyarakat itu. Wujud ini sering pula disebut dengan sistem sosial. Sistem sosial 
ini terdiri dari aktivitas-aktivitas manusia yang saling berinteraksi, mengadakan kontak, serta bergaul dengan manusia lainnya menurut pola-pola tertentu yang berdasarkan adat tata kelakuan. Sifatnya konkret, terjadi dalam kehidupan sehari-hari, dan dapat diamati dan didokumentasikan.

3. Artefak (karya)

Artefak adalah wujud kebudayaan fisik yang berupa hasil dari aktivitas, perbuatan, dan karya semua manusia dalam masyarakat berupa benda-benda atau hal-hal yang dapat diraba, dilihat, dan didokumentasikan. Sifatnya paling konkret diantara ketiga wujud kebudayaan.

Dakwah merupakan panggilan atau seruan bagi umat manusia menuju jalan Allah, ${ }^{10}$ yaitu jalan menuju Islam. Sebagai dinullah, Islam bersumber dari wahyu Allah SWT dan sunnah Rasul-Nya, ia merupakan sumber nilai yang akan memberikan corak, warna dan bentuk kebudayaan Islam. Suatu bentuk kebudayaan yang berisikan pesan atau nilai-nilai islami, sekalipun ia muncul dari orang atau masyarakat bukan penganut dînul Islam.

Demikian juga sebaliknya, tidak dikatakan budaya Islam, walau ia lahir dari orang atau masyarakat penganut dinul Islam, jika tidak memuat pesan atau nilai-nilai Islami. Pada hakekatnya, dakwah Islam merupakan aktualisasi imani (theologis) yang dimanifestasikan dalam suatu sistem kegiatan manusia beriman dalam bidang kemasyarakatan yang dilaksanakan secara teratur untuk mempengaruhi cara merasa, berfikir, bersikap dan bertindak manusia pada dataran kenyataan individual dan sosiokultural dalam rangka mengusahakan terwujudnya ajaran Islam dalam semua segi kehidupan dengan menggunakan cara tertentu. Dalam perspektif dakwah Islam, budaya atau kebudayaan adalah aktualisasi dari sikap

\footnotetext{
${ }^{10}$ Fachry Ali, AgamaIslam dan Pembangunan,
} (Yogyakarta: PLP2M, 1985) hlm: 27 tunduk (ibadah atau peribadatan) manusia kepada Allah.

Al Qur'an dan Budaya:

Dalam Al-Qur'an ditemui 6 surat yang berkaitan dengan pemberdayaan budaya masyarakat Islam antara lain : Q.S. Al Ahzab 33:61,Q.S. Ali Imran 3:102,Q.S. Al Mumtahanah 60:2,Q.S. Al Anfal 8:57,Q.S. An Nisa' 4:91,Q.S. Al Bakarah 2:191. ${ }^{11}$ Q.S. An Nisa' 4:91

Artinya : kelak kamu akan dapati (golongangolongan) yang lain, yang bermaksud supaya mereka aman dari pada kamu dan aman (pula) dari kaumnya. Setiap mereka diajak kembali kepada fitnah (syirik), merekapun terjun kedalamnya. karena itu jika mereka tidak membiarkan kamu dan (tidak) mau mengemukakan perdamaian kepadamu, serta (tidak) menahan tangan mereka (dari memerangimu), Maka tawanlah mereka dan bunuhlah mereka dan merekalah orang-orang yang Kami berikan kepadamu alasan yang nyata (untuk menawan dan membunuh) mereka.

Pada ayat-ini Allah SWT menerangkan bahwa selain kedua golongan orang-orang kafir tersebut di atas, kaum Muslimin bakal menemukan juga suatu golongan lain dengan ciri-ciri dan niat yang berbeda. Mereka ini adalah orang-orang kafir munafik, yaitu munafik dalam hal kepercayaan.

Apabila mereka bertemu dengan kaum Muslimin mereka menyatakan diri sebagai orang-orang yang beragama Islam, dan apabila mereka berada bersama orangorang kafir, mereka mengatakan tetapseagama dengan mereka dan tetap menyembah patung bersama mereka. Hal itu mereka lakukan karena menjaga keamanan diri, keluarga dan harta benda mereka

\footnotetext{
${ }^{11}$ Muhammad Fuad Abdul al Baqi, Al-Mu'jam al Mufarahros li alfadhil al Qur'anil Karim, (Indonesia: Maktabah duhlan). H. 202
} 
terhadap gangguan kaum Muslimin dan gangguan dari golongan mereka sendiri.

Allah berfirman mengenai mereka ini :

Artinya : dan bila mereka berjumpa dengan orang-orang yang beriman, mereka mengatakan: "Kami telah beriman". dan bila mereka kembali kepada syaitan-syaitan mereka, mereka mengatakan: "Sesungguhnya Kami sependirian dengan kamu, Kami hanyalah berolok-olok."

Al Qur'an yang di turunkan kepada Nabi Muhammad SAW, di fahami oleh sebagian orang bahwa Al Qur'an adalah hasil karya sastra terbesar arab, dan di fahami bahwa Al Qur'an terbentuk dari kebudayaan arab. Jika dilihat dari aspek kebudayaan dan sastra, Al Qur'an mengandung sastra yang terbesar dan memunculkan peradaban yang menghantarkan masyarakat yang tanpa peradaban menjadi masyarakat yang berperadaban moderat pada masa itu.

Budaya yang muncul dari hasil karya sastra manusia yang membentuk kebudayaan terkadang bertentangan dengan kebudayaan lain maka bisa di simpulkan budaya bersifat relative, bagaimana dengan Al Qur'an?.

Relativitas budaya yang muncul dari gagasan manusia sangat terbatas, karena akal dan gagasan manusia terbatas pada ruang dan waktu, sehingga budaya yang lahir dari gagasan terpengaruh oleh kondisi masyarakat sekitar. Keterbatasan gagasan manusia oleh akal dan waktu tidak memungkinkan untuk memunculkan berita masa lalu dan masa mendatang, hal ini bertolak belakang dengan $\mathrm{Al}$ Qur'an yang berisi berita masa lalu yang telah terkubur ribuan tahun serta berita masa mendatang yang datang ribuan tahun setelah $\mathrm{Al}$ Qur'an diturunkan, hal lain yang tidak mungkin adalah kondsi masyarakat arab sebelum Islam yang hidup tanpa peradaban dan budaya dapat memunculkan gagasan yang berupa Al Qur'an, hal lain yang membuktikan bahwa Al Qur'an bukanlah produk budaya ataupun terpengaruh budaya arab pada masa waktu itu adalah keterangan ilmiyah yang terdapat dalam $\mathrm{Al}$ Qur'an, seperti : proses penciptaan manusia, pergantian siang dan malam, ilmu tentnag laut, dan ilmu perbintangan. Keterangan ilmiyah ini tidak mungkin akan di lahirkan oleh budaya arab pada masa itu yang berada pada keterbelakangan dan keterpurukan peradaban.

Dari fakta dan data yang ada, telah membuktikan bahwa Al Qur'an merupakan kitab samawi yang murni dan tidak terpengaruh oleh budaya lokal pada masa itu, keotentikanya terjaga dari percampuran budaya arab yang penuh keterbelakangan.

\section{Kesimpulan}

Kata ekonomi diartikan ke bahasa arab yaitu al-iqtishad (الأقتصاد) yang berasal dari kata (قصد) yang berarti maksud, yang al-iqtishad itu dimaknai melakukan sesuatu atau mengatur sesuatu sesuai dengan ketentuan dan aturanaturannya, tidak kurang dan tidak lebih. maka intisari atau tashrifnya (bentuk perubahannya) dari kata ini terdapat dalam al-Qur'an pada 5 surat diantaranya: Surat An-Nahl 16:9, AlLuqman 31:19,32, Al-Maidah 5:66, At-Taubah 9:42, Al-Fathir 35:32. Ekonomi Islam merupakan ilmu yang mempelajari perilaku ekonomi manusia yang perilakunya diatur berdasarkan aturan agama Islam dan didasari dengan tauhid sebagaimana dirangkum dalam rukun iman dan rukun Islam.

Politik sangat dekat dengan kepemimpinan, secara sederhana kepemimpinan transformasional dapat diartikan sebagai proses untuk merubah dan mentransformasikan individu agar mau berubah dan meningkatkan dirinya, yang didalamnya melibatkan motif dan pemenuhan kebutuhan serta penghargaan terhadap para bawahan.

Pemberdayaan sosial merupakan upaya yang diarahkan untuk mewujudkan warga negara yang mengalami masalah sosial agar mempunyai daya, sehingga mampu memenuhi kebutuhan dasarnya (UU Nomor 112009 tentang Kesejahteraan Sosial). Pengertian ini 
mesti dimaknai secara arif, yaitu bahwa tujuan pemenuhan kebutuhan dasar adalah tujuan awal agar secara bertahap kehidupan yang lebih berkualitas dan kemandirian dapat dicapai. Pemberdayaan sosial secara simultan juga diarahkan agar seluruh potensi kesejahteraan sosial dapat dibangun menjadi sumber kesejahteraan sosial yang mampu berperan optimal dalam penyelenggaraan kesejahteraan sosial.

Mengenai kebudayaan yaitu sistem pengetahuan yang meliputi sistem ide atau gagasan yang terdapat dalam pikiran manusia, sehingga dalam kehidupan sehari-hari, kebudayaan itu bersifat abstrak.Sedangkan perwujudan kebudayaan adalah benda-benda yang diciptakan oleh manusia sebagai makhluk yang berbudaya, berupa perilaku dan bendabenda yang bersifat nyata, misalnya pola-pola perilaku, bahasa, peralatan hidup, organisasi sosial, religi, seni, dan lain-lain, yang kesemuanya ditujukan untuk membantu manusia dalam melangsungkan kehidupan bermasyarakat, sehingga bisa disimpulkan bahwa hasil karya cipta manusia memunculkan budaya, dan kebudayaan akan menciptakan peradaban.

Pendidikan Islam itu sendiri adalah pendidikan yang berdasarkan Islam. Isi ilmu adalah teori. Isi ilmu bumi adalah teori tentang bumi. Maka isi Ilmu pendidikan adalah teoriteori tentang pendidikan, Ilmu pendidikan Islam secara lengkap isi suatu ilmu bukanlah hanya teori.

\section{Daftar Pustaka}

Fadhlu 'Abdi al-Rahman Biafdhola, dkk, AlQur'an dan Terjemahnya, (Bandung : CV Penerbit J-ART, 2005), hlm.87

Hamka, Tafsir Al-Azhar, Penerbit Pustaka Panjimas, Jakarta

http://fahmyzone.blogspot.com/2013/04/penger tian-ekonomi-

Islam.html\#sthash.uHXlpydI.dpuf
Kamus Besar Bahasa Indonesia.

Muhammad Fuad Abdul al Baqi, Al-Mu'jam al Mufarahros li alfadhil al Qur'anil Karim, (Indonesia: Maktabah duhlan).

M. Quraish Shihab, "WAWASAN AL-QURAN Tafsir Maudhu'i atas Pelbagai Persoalan Umat

(ebookby.nazilhilmie@yahoo.com,)

http://e-coversance.blogspot.com/2011/02/ilmupengetahuan-umum-dalam-agama-

Islam.html diakses pada tanggal $0 / 11 / 2015$

An-Nahlawi, Abdurrahman.. Prinsip-prinsip dan Metode Pendidikan Islam.(Bandung : CV. Diponegoro. 1992).

Fachry Ali, AgamaIslam dan Pembangunan, (Yogyakarta: PLP2M, 1985)

Asep Muhyiddin dan Agus Ahmad Safei, Metode Pengembangan Dakwah, Bandung: Pustaka Setia, 2002,

Taufik Abdullah, "Pengantar: Islam, Sejarah dan Masyarakat",dalam Taufik Abdullah Sejarah dan Masyarakat:Lintasan Historis Islam di Indoensia, (Jakarta: PustakaFirdaus, 1987)

M. Dawam Rahardjo, Aspek Pembaharuan Pemahaman Islam, dalam Dakwah Islam dan Perubahan Sosial, Yogyakarta: Prima Duta, 1983

Muhammad, Lembaga-lembaga Keuangan Ummat Kontemporer (Cet.I; Yogyakarta: UII Press, 2000)

Karnaen A. Perwataatmadja, Membumikan Ekonomi Islam di Indonesia (Depok: Usaha Kami, 1996) 